\title{
By-products from integrated starch-ethanol production from barley in the diets of growing cattle
}

\author{
PEKKA HUHTANEN, MATTI NÄSI and HANNELE KHALILI \\ Department of Animal Husbandry, University of Helsinki \\ SF-00710 Finland
}

\begin{abstract}
Two experiments were carried out to evaluate the nutritive value for growing cattle of by-products from a new process for integrated starch-ethanol production from barley. Experiment 1 was a $4 \times 4$ Latin Square, in which the effects of barley protein $(375 \mathrm{~g}$ crude protein (CP)/ $\mathrm{kg}$ dry matter (DM)) on digestibility and $\mathrm{N}$ retention were examined in four male cattle (initial live weight ( $\mathrm{LW}) 147 \mathrm{~kg}$ ). The control diet $(\mathrm{C})$ consisted of hay and rolled barley (1: 1). In isonitrogenous experimental diets, soybean meal (S), a mixture of soybean meal and barley protein (SB) or barley protein (B) was substituted for barley to increase the dietary CP content from 125 to $150 \mathrm{~g} / \mathrm{kg} \mathrm{DM}$.

Replacement of barley with protein supplements increased $(\mathrm{P}<0.01)$ the apparent digestibility of $\mathrm{CP}$ but had no effect on organic matter (OM) digestibility. Gradual replacement of soybean meal with barley protein decreased $\mathrm{N}$ retention linearly $\left(\mathrm{P}^{\prime}<0.05\right)$ from 32.0 to $28.9 \mathrm{~g} / \mathrm{d}$. Increasing the supply of $\mathrm{CP}$ by including barley protein in the diet had no effect on $\mathrm{N}$ retention.

In experiment 2 the effects of barley fibre ( $566 \mathrm{~g} \mathrm{NDF} / \mathrm{kg} \mathrm{DM}, 137 \mathrm{~g} \mathrm{CP} / \mathrm{kg} \mathrm{DM}$ ) as an energy supplement for growing cattle given grass silage ad libitum were examined. In a $3 \times 2$ factorial experiment the three energy supplements were barley $(\mathrm{B})$, barley + barley fibre $(1: 1$, BF) and barley fibre (F), each fed without and with $0.5 \mathrm{~kg}$ of rapeseed meal (RSM) per day. The supplements including RSM were fed at the rate of $45 \mathrm{~g} \mathrm{DM} / \mathrm{kg} \mathrm{LW} 0.75$. The experiment involved 24 bulls (initial LW $165 \mathrm{~kg}$ ) and the treatments were imposed for 224 days.

The silage used was of high quality in terms of both digestibility and fermentation parameters. RSM had no effect on silage DM intake or LW gain. During the first 16 weeks of the study the cattle given RSM tended $(\mathrm{P}<0.06)$ to grow faster than those fed without additional protein, but this advantage entirely disappeared during the last 16 weeks of the study. Replacing barley with barley fibre resulted in a non-significant $(P>0.1)$ linear decrease in $L W$ gain (from 1278 to $1214 \mathrm{~g} / \mathrm{d}$ ). Feed conversion rate in terms of feed units per $\mathrm{kg} \mathrm{LW}$ gain improved linearly $(\mathrm{P}<0.05)$ with the level of barley fibre. Carcass characteristics were not significantly affected by the diet given.
\end{abstract}

Index words: barley protein, barley fibre, barley, rapeseed meal, silage, growing cattle 


\section{Introduction}

By-products from a new process for integrated starch-ethanol production from barley (Alko Ltd., Helsinki) are now available in Finland. The process, chemical composition and feed values of the products have been described by Näsı (1988). One of the byproducts is barley fibre, consisting of the cell wall fraction of the endosperm ( $550 \mathrm{~g}$ neutral detergent fibre/kg dry matter (DM), $120 \mathrm{~g}$ starch/kg DM). In dairy cows given grass silage ad libitum the performance with barley fibre was found to be equal to (HUHTANEN $e t$ al. 1988) or higher than (Ala-Seppälä et al. 1988 ) the performance with barley. High performance on barley fibre diets in spite of reduced estimated energy intake may be the result of improved forage digestibility, changes in the rumen fermentation pattern or nutrient partitioning.

Barley protein is another by-product from the same process. The protein content of barley protein is equal to or slightly higher than that of rapeseed meal, the most important domestic protein supplement in ruminant diets in Finland. The supply of amino acids to the tissues is often limiting the growth rate of cattle given grass silage based diets, and protein supplements have produced large responses in growth rate (eg. WATERHOUSE et al. 1983, Huhtanen et al. Gill et al. 1987, JaAkKola et al. 1989). Although the high crude protein content of barley protein makes it an attractive protein supplement for growing cattle, the protein degradability may be greater than that of oilseed meals, and the amino acid composition of the undegraded protein may not be ideal.

The effects of including these two byproducts in the diets of growing cattle were studied in two experiments. In the first experiment the effect of barley protein on nutrient digestibility and $\mathrm{N}$ retention was studied relative to the effect of soybean meal. The second experiment was planned to study the effect of replacing barley with barley fibre and inclusion of protected rapeseed meal in the diet on the performance of growing cattle given grass silage ad libitum.

\section{Material and methods}

\section{Experiment 1}

Four intact male cattle (initial live weight (LW) $147 \mathrm{~kg}$; SE 12) were used in a $4 \times 4$ Latin Square experiment to study the effects of barley protein from integrated starch-ethanol production (NÄSı 1988) as a protein source for growing cattle. The control diet (C) consisted of hay and barley (1:1). Organic matter $(\mathrm{OM})$ digestibility of the hay was 0.615 in sheep. In isonitrogenous experimental diets, soybean meal $(\mathrm{S})$, a mixture $(1: 1$ on crude protein (CP) basis) of soybean meal and barley protein (SB) and barley protein (B) were used to increase the dietary CP content from 125 to $150 \mathrm{~g} / \mathrm{kg}$ dry matter (DM). The compositions of the experimental diets are given in Table 1. Water was freely available and $100 \mathrm{~g}$ of a commercial mineral mixture was given daily. The feeding level was $90 \mathrm{~g} \mathrm{DM} / \mathrm{kg}$ $\mathrm{LW}^{0.75}$ based on the initial $\mathrm{LW}$ at the beginning of each period.

The animals were kept in metabolism cages allowing a separate collection of faeces and urine. Each experimental period lasted $21 \mathrm{~d}$, of which adaptation and standardization comprised $14 \mathrm{~d}$ and total collection of faeces and urine was made during the final $7 \mathrm{~d}$. The procedures used for faecal and urine collection, the feed sampling and methods of chemical analyses have been described by HUнтA. Nen and Poutiainen (1985).

Table 1. Formulation of experimental diets ( $g$ DM/ $\mathrm{kg}$ DM) in Exp. 1.

\begin{tabular}{lcrrc}
\hline & \multicolumn{4}{c}{ Diet } \\
\cline { 2 - 5 } & C & \multicolumn{1}{c}{ S } & SB & B \\
\hline Hay & 500 & 500 & 500 & 500 \\
Barley & 500 & 430 & 417 & 405 \\
Soybean meal & - & 70 & 35 & - \\
Barley protein & - & - & 48 & 95 \\
\hline
\end{tabular}


The analyses of variance for Latin Square experiments were made. The sums of squares for treatment effect were further separated into single degrees of freedom for comparisons of diet $\mathrm{C}$ with the three other diets, and into linear and quadratic effects of the replacement of soybean meal with barley protein (SNedecor and Cochran 1967).

\section{Experiment 2}

\section{Design and diets}

A $3 \times 2$ factorial experiment was designed to compare barley (B), a mixture (1:1 on DM basis) of barley and barley fibre (BF) and barley fibre (F) as energy supplements, each given without additional protein (C) or supplemented with rapeseed meal $(\mathrm{R})$ to growing bulls given grass silage ad libitum. Barley fibre obtained from integrated starch-ethanol production consists mainly of the cell wall fraction of the endosperm (NÄsı 1988). Barley was fed in crushed form. Rapeseed meal (RSM) was treated for reduced degradability of $\mathrm{N}$ in the rumen (Öljynpuristamo Ltd., Helsinki, Finland). The concentrate supplements, including $0.5 \mathrm{~kg}$ of RSM on R diets, were given at the rate of $45 \mathrm{~g} \mathrm{DM} / \mathrm{kg} \mathrm{LW}^{0.75}$ based on the initial LW of each $28 \mathrm{~d}$ experimental period. A commercial mineral mixture was supplied at the rate of $100 \mathrm{~g} / \mathrm{d}$ throughout the experiment. All the ingredients of the concentrate mixture were weighed separately and mixed prior to feeding. Grass silage was made from timothy-meadow fescue sward, which was harvested after a wilting period of $4-6 \mathrm{~h}$ using a precision-chop forage harvester and ensiled in a bunker silo with a formic acid based additive (AIV II; $800 \mathrm{~g}$ formic acid/ $\mathrm{kg}$, $20 \mathrm{~g}$ orthophoshoric acid $/ \mathrm{kg}$ ) applied at the rate of $4-5 \mathrm{l} / \mathrm{t}$.

\section{Animals and management}

Animals were 12 Ayrshire bulls with a mean initial LW of $154 \mathrm{~kg}$ (SE 7.5) and 12 Friesian bulls with a mean initial LW of $172 \mathrm{~kg}$ (SE $11.3 \mathrm{~kg}$ ). These were divided into four blocks by breed and LW, and within each block allocated to the treatments at random. All the animals were housed and fed individually twice daily. The treatments were imposed for 228 days ( 8 periods of 28 days).

\section{Measurements}

Samples of feeds offered were taken weekly and analysed for DM. Silage samples were bulked over 4 weeks and concentrate samples over 8 weeks to provide the samples for analyses. The analytical methods have been described by HuHTANEn (1987). Feeds offered were weighed daily and refusals were recorded on 5 consecutive days per week. The animals were weighed on two consecutive days at the beginning and end of the experiment, and otherwise every 4 weeks. LW gains were calculated for each animal, either by difference method or from a second degree polynomial regression of LW on time.

All the cattle were slaughtered at the end of the experiment. Dressing proportions were calculated from hot carcass weight. The carcass quality and fatness were graded visually using the carcass classification scheme employed in commercial slaughterhouses in Finland.

To evaluate energy utilization, metabolizable energy (ME) requirements were calculated for each animal for each $28 \mathrm{~d}$ experimental period using the equations proposed by the Agricultural Research Council (ARC 1980). ME values for the feeds were calculated according to the Ministry of Agriculture, Food and Fisheries (MAFF 1975). Corrected live weights and LW gains calculated from regression equations were used to estimate ME requirements.

The model used to analyse data was $\mathrm{y}_{\mathrm{ijkl}}=$ $\mu+E_{i}+P_{j}+(E P)_{i j}+B_{k}+e_{i j k k}$, where E, P and $\mathrm{B}$ are the effects of energy supplement, protein and breed. The effect of the energy supplement was further partitioned into linear and quadratic effects of the replacement of barley with barley fibre, using polynomial contrasts (SNEDECOR and CoChran 1967). Initial 
LW was used as covariate to analyse the data for feed conversion efficiency. Because there was no interaction between the energy supplement and additional protein, results are presented only for the main factors.

\section{Results}

The chemical composition and feed values of the experimental feeds are presented in Table 2. CP content of barley used in Exp. 1 was exceptionally high ( $155 \mathrm{~g} / \mathrm{kg}$ DM). Barley protein had a lower CP content than soybean meal (375 v. $527 \mathrm{~g} / \mathrm{kg}$ DM). The silage used in Exp. 2. was of high quality in terms of both fermentation characteristics and D-value.

\section{Experiment 1}

The digestibilities of the different dietary constituents are given in Table 3. There were no differences between the diets in the digestibility of OM, crude fibre or NFE. Apparent digestibility of $\mathrm{CP}$ was significantly $(\mathrm{P}<0.01)$ higher when protein supplements were given, but there were no differences between the pro-

Table 2. Chemical composition of the experimental feeds unless otherwise stated $(\mathrm{g} / \mathrm{kg}$ DM) and estimated feed values.

\begin{tabular}{|c|c|c|c|c|c|c|c|c|c|}
\hline & & \multicolumn{4}{|c|}{ Experiment 1} & \multicolumn{4}{|c|}{ Experiment 2} \\
\hline & & Hay & Barley & $\begin{array}{l}\text { Barley } \\
\text { protein }\end{array}$ & $\begin{array}{c}\text { Soybean } \\
\text { meal }\end{array}$ & $\begin{array}{l}\text { Grass } \\
\text { silage }\end{array}$ & Barley & $\begin{array}{c}\text { Barley } \\
\text { fibre }\end{array}$ & $\begin{array}{c}\text { Rapeseed } \\
\text { meal }\end{array}$ \\
\hline Dry matter $(\mathrm{g} / \mathrm{kg})$ & & 862 & 863 & 953 & 844 & 233 & 875 & 905 & 879 \\
\hline \multicolumn{10}{|l|}{ In dry matter } \\
\hline Ash & & 62 & 32 & 38 & 69 & 84 & 26 & 67 & 76 \\
\hline Crude protein & & 99 & 155 & 375 & 527 & 148 & 141 & 137 & 365 \\
\hline Ether extract & & 19 & 21 & 53 & 9 & 56 & 24 & 34 & 71 \\
\hline Crude fibre & & 354 & 58 & 14 & 78 & 297 & 52 & 146 & 131 \\
\hline $\mathrm{NFE}^{\prime}$ & & 466 & 734 & 519 & 316 & 414 & 758 & 616 & 358 \\
\hline NDF & & & & & & 518 & 177 & 566 & 241 \\
\hline ADF & & & & & & 309 & 43 & 153 & 174 \\
\hline ADL & & & & & & 25 & 10 & 23 & 79 \\
\hline \multicolumn{10}{|l|}{ Feed values } \\
\hline $\mathrm{FFU}^{2} / \mathrm{kg} \mathrm{DM}$ & & & & & & 0.727 & 1.160 & 0.904 & 0.989 \\
\hline $\mathrm{ME} \mathrm{MJ} / \mathrm{kg} \mathrm{DM}$ & & & & & & 10.25 & 13.55 & 10.79 & 11.88 \\
\hline $\mathrm{DCP}^{3} \mathrm{~g} / \mathrm{kg} \mathrm{DM}$ & & & & & & 104 & 105 & 105 & 303 \\
\hline
\end{tabular}

$1 \mathrm{NFE}=$ nitrogen free extracis ${ }^{2} \mathrm{FFU}=$ fattening feed unit $=0.7 \mathrm{~kg}$ starch,

${ }^{3} \mathrm{DCP}=$ digestible crude protein. In silage: $\mathrm{pH} 3.86$; in dry matter $(\mathrm{g} / \mathrm{kg})$ : lactic acid 66 , acetic acid 21 , propionic acid 0.5 , butyric acid 0.5 ; in total nitrogen $(\mathrm{g} / \mathrm{kg}): \mathrm{NH}_{3}-\mathrm{N} 47$, soluble $\mathrm{N} 552$; D-value 0.641 .

Table 3. Digestibility of the experimental diets (Exp. 1).

\begin{tabular}{|c|c|c|c|c|c|c|c|c|c|c|}
\hline \multirow[t]{2}{*}{. } & & \multirow{2}{*}{ 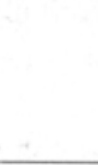 } & & \multicolumn{3}{|c|}{ Diet } & \multirow[t]{2}{*}{ SEM } & \multicolumn{3}{|c|}{$\begin{array}{c}\text { Statistical significance } \\
\text { of effect }\end{array}$} \\
\hline & & & $\mathrm{C}$ & $\mathrm{S}$ & $\mathrm{SB}$ & B & & $\begin{array}{l}\text { C v. } \\
\text { other }\end{array}$ & L & Q \\
\hline Dry matter & c & & 0.741 & 0.744 & 0.746 & 0.744 & 0.0043 & NS & NS & NS \\
\hline Organic matter & r. & & 0.755 & 0.758 & 0.759 & 0.758 & 0.0042 & NS & NS & NS \\
\hline Crude protein & & & 0.678 & 0.721 & 0.719 & 0.714 & 0.0080 & $* *$ & NS & NS \\
\hline Ether extract & & & 0.310 & 0.244 & 0.365 & 0.369 & 0.0193 & NS & $* *$ & $*$ \\
\hline Crude fibre & & & 0.663 & 0.674 & 0.667 & 0.669 & 0.0083 & NS & NS & NS \\
\hline NFE & & . & 0.818 & 0.816 & 0.816 & 0.815 & 0.0035 & NS & NS & NS \\
\hline
\end{tabular}

$\mathrm{SEM}=$ standard error of the means; significance: $\mathrm{NS}=$ non-significant; ${ }^{*}(\mathrm{P}<0.05) ;{ }^{* *}(\mathrm{P}<0.01)$.

$\mathrm{L}, \mathrm{Q}=$ linear and quadratic effects of replacing soybean meal with barley protein. 
tein supplements. Replacing soybean with barley protein increased significantly the digestibility of ether extract (linear effect $\mathrm{P}<0.01$; quadratic effect $\mathrm{P}<0.05$ ). For barley protein, $\mathrm{OM}$ and $\mathrm{CP}$ digestibilities, calculated by difference method were 0.902 and 0.828 and estimated energy values $1.20 \mathrm{FFU} / \mathrm{kg} \mathrm{DM}$ and 14.0 MJ ME/kg DM.

The results for intake and metabolism of $\mathrm{N}$ are given in Table 4. Since the amount of $\mathrm{N}$ excreted in faeces did not vary with the diet, the amount of $\mathrm{N}$ apparently absorbed was greater $(\mathrm{P}<0.001)$ in cattle given protein sup- plements. However, the amount of $\mathrm{N}$ excreted in urine was increased $(\mathrm{P}<0.001)$ by feeding additional protein, with the result that the difference in $\mathrm{N}$ retention between $\operatorname{diet} \mathrm{C}$ and other diets was small $(1.7 \mathrm{~g} / \mathrm{d})$ and nonsignificant. On the other hand, increasing the proportion of barley protein in the protein supplement caused the $\mathrm{N}$ retention to decrease linearly $(\mathrm{P}<0.05)$. In cattle given protein supplements, the proportion of $\mathrm{N}$ retained of $\mathrm{N}$ absorbed was lower $(\mathrm{P}<0.05)$, and a similar trend $(\mathrm{P}<0.1)$ was observed for the proportion of $\mathrm{N}$ retained of $\mathrm{N}$ intake.

Table 4. Intake, faecal and urine losses and retention of $\mathrm{N}(\mathrm{g} / \mathrm{d})$.

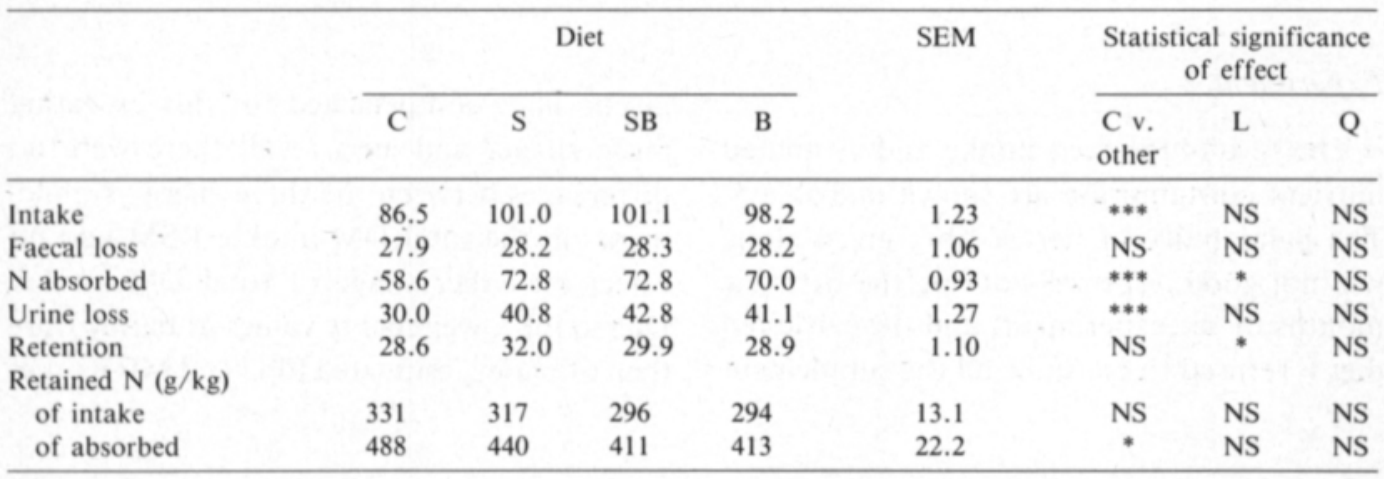

For significance: see Table 3.

Table 5. Feed intake (kg DM/d) and nutrient consumption in Exp. 2.

\begin{tabular}{|c|c|c|c|c|c|c|c|c|c|}
\hline \multirow[b]{4}{*}{. } & \multicolumn{3}{|c|}{ Supplement } & \multicolumn{2}{|c|}{ Protein } & \multirow{4}{*}{$\begin{array}{l}\text { SEM' } \\
17 \mathrm{df}\end{array}$} & \multirow{2}{*}{\multicolumn{3}{|c|}{$\begin{array}{c}\text { Statistical significance } \\
\text { of effect }\end{array}$}} \\
\hline & \multirow{3}{*}{. } & \multirow{3}{*}{$\mathrm{BF}$} & \multirow{3}{*}{$\mathrm{F}$} & \multirow{3}{*}{ C } & \multirow{3}{*}{$\mathbf{R}$} & & & & \\
\hline & & & & & & & \multicolumn{2}{|c|}{ Barley fibre } & \multirow[t]{2}{*}{ Protein } \\
\hline & & & & & & & L & Q & \\
\hline Grass silage & 3.91 & 3.90 & 4.27 & 4.07 & 3.98 & 0.12 & NS & NS & NS \\
\hline Barley & 2.79 & 1.43 & - & 1.50 & 1.32 & 0.10 & - & - & - \\
\hline Barley fibre & - & 1.40 & 2.43 & 1.34 & 1.20 & 0.05 & - & - & - \\
\hline Rapeseed meal & 0.21 & 0.22 & 0.20 & - & 0.42 & 0.003 & - & - & - \\
\hline Total DM intake & 6.90 & 6.95 & 6.90 & 6.91 & 6.92 & 0.19 & NS & NS & NS \\
\hline \multicolumn{10}{|l|}{ DM intake as } \\
\hline $\mathrm{g} / \mathrm{kg} \mathrm{W} \mathrm{W}^{0.75}$ & 97.1 & 95.1 & 98.6 & 97.0 & 96.8 & 1.39 & NS & NS & NS \\
\hline $\mathrm{FFU} / \mathrm{d}$ & 6.31 & 6.00 & 5.53 & 5.94 & 5.95 & 0.17 & $* *$ & NS & NS \\
\hline $\mathrm{ME} \mathrm{MJ/d}$ & 80.7 & 77.4 & 72.9 & 77.0 & 77.0 & 2.22 & $*$ & NS & NS \\
\hline DCP g/d & 781 & 783 & 778 & 739 & 822 & 20.9 & NS & NS & $* *$ \\
\hline
\end{tabular}

$\mathrm{SEM}=$ standard error of means .

Significance: NS (non-significant), ${ }^{*}(\mathrm{P}<0.05),{ }^{* *}(\mathrm{P}<0.01),{ }^{* * *}(\mathrm{P}<0.001)$.

I SEM of the energy supplements, SEM of protein supplements is $0.816 \times$ SEM of energy supplements. 


\section{Liveweight gain, $\mathrm{kg} / \mathrm{d}$}

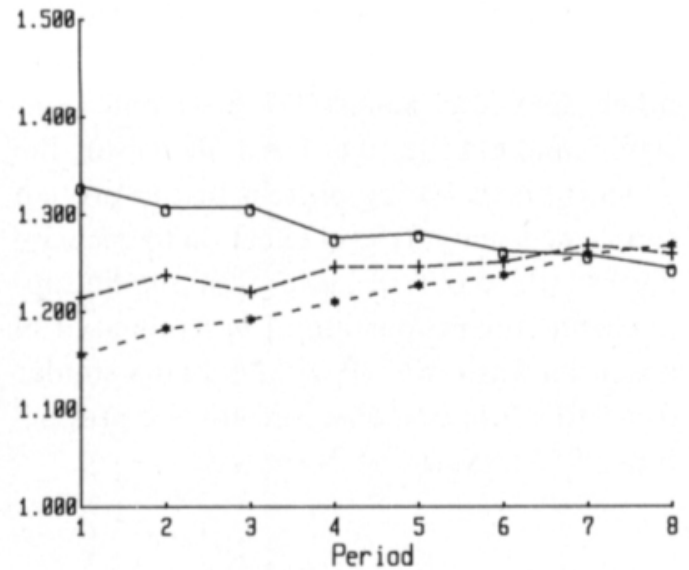

Liveweight gain, $\mathrm{kg} / \mathrm{d}$

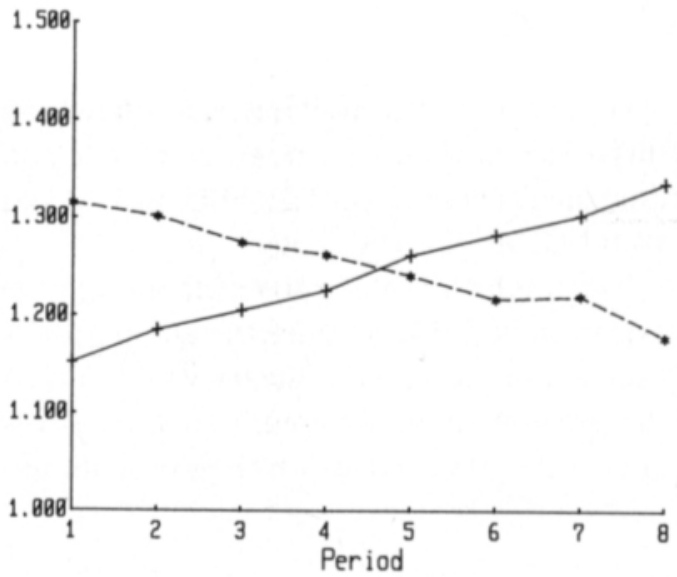

Fig. 1. Daily liveweight gain during the experiment. Left: $\operatorname{diet} \mathrm{B}(\mathrm{O})$, diet $\mathrm{BF}(+)$, diet $\mathrm{F}(*)$; right $\operatorname{diet} \mathrm{C}(+)$, diet $\mathbf{R}\left({ }^{*}\right)$.

\section{Experiment 2}

The results for feed intake and estimated nutrient consumption are shown in Table 5. The palatability of barley fibre given alone was not good, especially during the first few months of the experiment, and the cattle fed diet $\mathrm{F}$ refused to consume all the supplement given. They compensated for this by eating more silage, and as a result there were no differences between the three energy supplements in the total DM intake. RSM had no effect on either silage or total DM intake. Due to the lower energy values of barley fibre than of barley, estimated FFU and ME intakes

Table 6. Animal production data in Exp. 2.

\begin{tabular}{|c|c|c|c|c|c|c|c|c|c|}
\hline & \multicolumn{3}{|c|}{ Supplement } & \multicolumn{2}{|c|}{ Protein } & \multirow{4}{*}{$\begin{array}{l}\text { SEM } \\
17 \mathrm{df}\end{array}$} & \multirow{2}{*}{\multicolumn{3}{|c|}{$\begin{array}{c}\text { Statistical significance } \\
\text { of effect }\end{array}$}} \\
\hline & \multirow[t]{3}{*}{ B } & \multirow{3}{*}{$\mathrm{BF}$} & \multirow[t]{3}{*}{$\mathrm{F}$} & \multirow{3}{*}{$\mathrm{C}$} & \multirow[t]{3}{*}{$\mathbf{R}$} & & & & \\
\hline & & & & & & & \multicolumn{2}{|c|}{ Barley fibre } & \multirow[t]{2}{*}{ Protein } \\
\hline & & & & & & & L & Q & \\
\hline Initial weight, kg & 158 & 176 & 161 & 168 & 162 & 13.2 & NS & NS & NS \\
\hline Final weight, kg & 444 & 455 & 432 & 445 & 441 & 13.4 & NS & NS & NS \\
\hline LW gain, g/d' & 1278 & 1251 & 1214 & 1246 & 1249 & 33 & NS & NS & NS \\
\hline LW gain, g/d² & 1277 & 1240 & 1203 & 1239 & 1241 & 34 & NS & NS & NS \\
\hline \multicolumn{10}{|l|}{ Feed conversion } \\
\hline $\mathrm{Kg} \mathrm{DM} / \mathrm{LW}$ gain & 5.49 & 5.47 & 5.76 & 5.44 & 5.60 & 0.141 & NS & NS & NS \\
\hline FFU/LW gain & 5.00 & 4.72 & 4.61 & 4.75 & 4.81 & 0.116 & $*$ & NS & NS \\
\hline DCP/LW gain & 620 & 618 & 648 & 592 & 665 & 16.3 & NS & NS & $* *$ \\
\hline Carcass weight, $\mathrm{kg}$ & 224 & 230 & 216 & 224 & 223 & 7.8 & NS & NS & NS \\
\hline Dressing $-\%$ & 51.9 & 52.0 & 51.4 & 51.6 & 51.9 & 0.47 & NS & NS & NS \\
\hline Quality grade' & 8.5 & 8.6 & 8.3 & 8.3 & 8.6 & 0.24 & NS & NS & NS \\
\hline Fatness grade ${ }^{2}$ & 4.8 & 4.8 & 4.9 & 4.9 & 4.8 & 0.13 & NS & NS & NS \\
\hline
\end{tabular}

For significance: see Table 3.

1 Calculated by regression

2 Calculated by difference

${ }^{3} 10=$ best quality

${ }^{4} 6=$ leanest 


\section{Diet $B$}

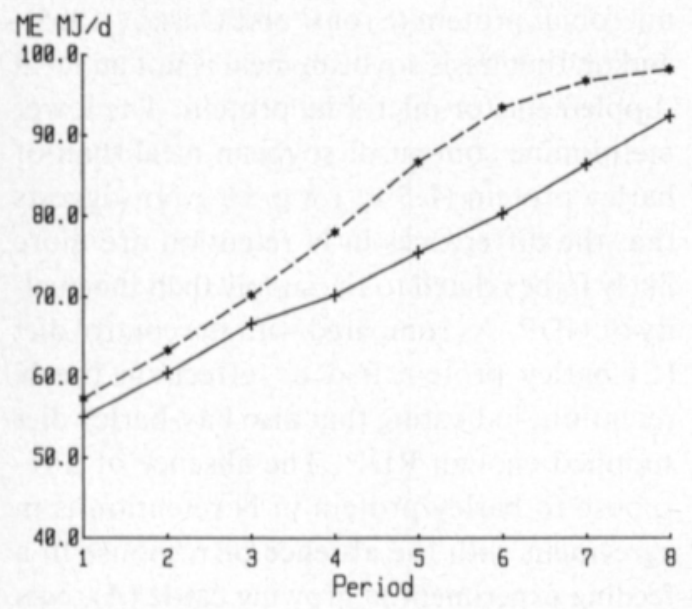

Diet BF

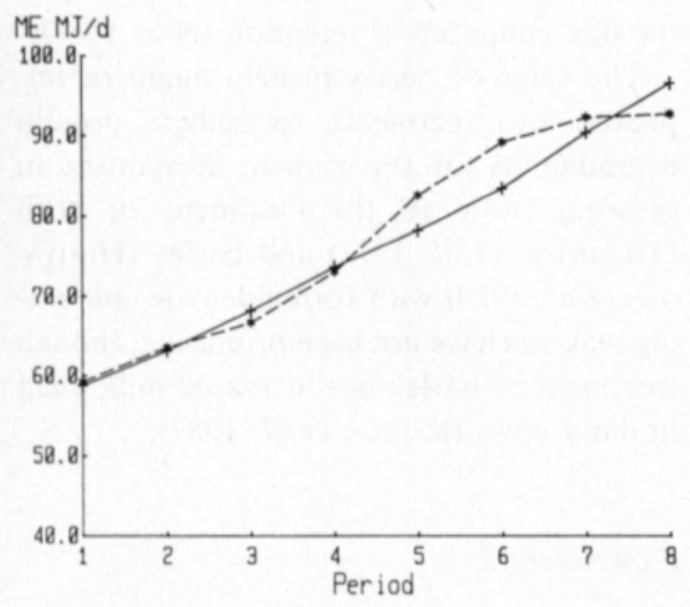

Diet $F$

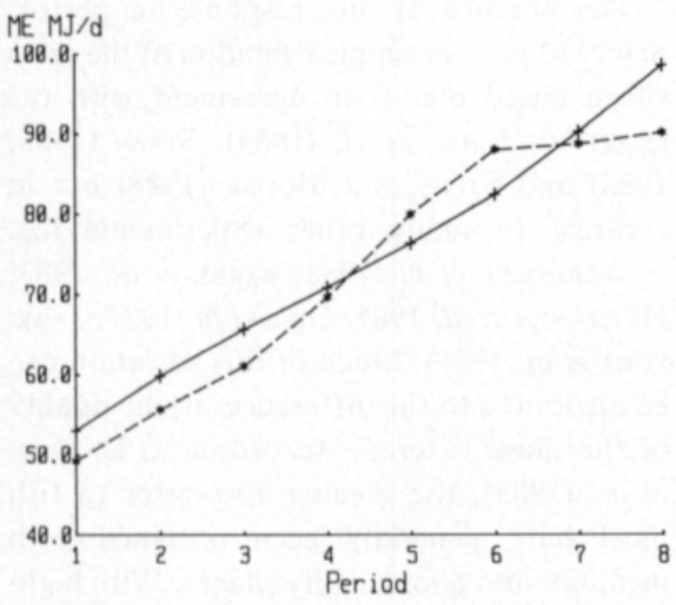

Fig. 2. ME requirement $(+)$ and ME supply (*) during the experiment in cattle given the three energy supplements. decreased linearly $(\mathrm{P}<0.01)$ with increasing level of barley fibre in the diet.

With increasing level of barley fibre in the diet, LW gain decreased from $1278 \mathrm{~g} / \mathrm{d}$ to $1214 \mathrm{~g} / \mathrm{d}(\mathrm{P}>0.1)$ (Table 6). Differences between the energy supplements in their effect on LW gain were greater during the first 112 days (4 periods), diminishing towards the end of the experiment (Fig. 1). RSM supplementation failed to enhance the $\mathrm{LW}$ gain during the experimental period as a whole. Although cattle given RSM had a substantially higher LW gain during the first 112 days (1293v . $1200 \mathrm{~g} / \mathrm{d}$; SEM 33), this increase was totally lost by a faster gain during the last 112 days of the cattle fed without extra protein.

Feed conversion rate in terms of $\mathrm{kg} \mathrm{DM} / \mathrm{kg}$ LW gain was not significantly affected by the energy supplements, but in terms of FFU/ kg LW gain, feed conversion was linearly improved $(\mathrm{P}<0.05)$ with the level of barley fibre in the diet. Cattle given RSM used more $\mathrm{DCP} / \mathrm{kg} \mathrm{LW}$ gain than those not given additional protein.

There were no significant differences in carcass weight or carcass quality between the treatments (Table 7). Differences in carcass weight reflected differences in the initial LW and daily gain, because the dressing proportion was not affected by the diet given.

Estimated ME supplies and calculated ME requirements for cattle given different energy supplements (B, BF and F) are shown in

Table 7. Comparison of observed data with requirements proposed by ARC (1984).

\begin{tabular}{|c|c|c|c|c|}
\hline & \multicolumn{4}{|c|}{ Diet } \\
\hline & C & $\mathrm{S}$ & SB & B \\
\hline RDN supplied' & 66.1 & 72.6 & 75.1 & 75.4 \\
\hline RDN required & 63.3 & 61.3 & 62.8 & 61.8 \\
\hline UDN supplied & 20.5 & 28.3 & 26.0 & 22.8 \\
\hline UDN required & 25.2 & 32.0 & 27.6 & 26.8 \\
\hline Tissue $\mathrm{N}^{2}$ & 48.4 & 52.6 & 51.8 & 49.1 \\
\hline
\end{tabular}

1 Assuming nitrogen degradabilities of hay, barley, soybean meal and barley protein to be $0.70,0.80,0.60$ and 0.80 .

2 Calculated according to ARC 1984. 
Fig. 2. In cattle given B diets, ME supply exceeded the ME requirement by $6.6 \mathrm{MJ} / \mathrm{d}$ and in cattle given $\mathrm{F}$ diets the ME supply was $2.7 \mathrm{MJ} / \mathrm{d}$ smaller than the calculated requirement. On BF diet ME supply met the requirement closely during the whole experiment.

\section{Discussion}

\section{Experiment 1}

Rumen microbial protein synthesis cannot supply enough amino acids for cattle weighing $100-200 \mathrm{~kg}$ when daily gains exceed $1 \mathrm{~kg}$ (ARC 1984), and protein supplements are widely used to increase LW gain. The animals used in the present study were at this range of LW, and ME supply was sufficient to allow daily gains above $1 \mathrm{~kg}$. This argues that differences in protein supply or quality would be reflected in changes in $\mathrm{N}$ retention.

The relationship between the supply of $\mathrm{N}$ to the body tissues calculated as proposed by Arc (1984) was fairly close to the observed N retention (Table 7). When protein supplements were given, $\mathrm{N}$ retention increased with the supply of rumen undegradable protein (UDP). Rumen degradability of barley protein cannot be determined by nylon bag technique owing to the small particle size, and the value $(0.80)$ for the ruminal degradability of $\mathrm{N}$ of barley was used instead. The real value may in fact be higher, since barley protein does not contain any cell wall bound $\mathrm{N}$. Higher buffer solubility (McDougall) of barley protein $(0.291)$ than of barley $(0.244)$ and soybean meal $(0.095)$ also points to a higher degradability of barley protein.

Higher $\mathrm{N}$ retention in cattle given diet $\mathrm{S}$ than in those given the control diet indicated that the hay-barley diet did not supply sufficient amino acids to the tissues for maximal protein deposition. Reduced $\mathrm{N}$ retention with increasing level of barley protein in the protein supplement suggests either differences in the flow of UDP at the duodenum or in the quality of UDP. Methionine has been suggest- ed to be the first limiting amino acid in microbial protein (STORM and ØRSKOV 1985), and on that basis soybean meal is not an ideal supplement for microbial protein. The lower methionine content of soybean meal than of barley protein $(1.5 v .1 .8 \mathrm{~g} / 16 \mathrm{~g} \mathrm{~N})$ suggests that the differences in $\mathrm{N}$ retention are more likely to be related to the supply than the quality of UDP. As compared with the control diet (C) barley protein had no effect on the $\mathrm{N}$ retention, indicating that also hay-barley diet supplied enough RDP. The absence of a response to barley protein in $\mathrm{N}$ retention is in agreement with the absence of response in a feeding experiment in growing cattle (ARONEN 1988). However, in sheep fed a hay-based diet, increasing the proportion of barley protein in the diet enhanced $\mathrm{N}$ retention (NÄsı 1988).

The value of barley protein might be improved by treatments to reduce protein degradability in the rumen. Responses in growing cattle to the treatment of corn (Thornton et al. 1977) and barley (HuhtANEN et al. 1985) with formaldehyde containing reagents have not been promising, though treatment of barley has increased milk yield in dairy cows (KASSEM et al. 1987).

\section{Experiment 2}

\section{Protein supplementation}

The absence of any response in performance to protein supplementation of the grass silage based diet is in agreement with the results of Kirby et al. (1984), STEEN (1985, 1988) and Steen and Moore (1988) but in contrast to many other experiments (eg. WAterhouse et al. 1983, KirBy et al. 1983, HuHtANEn et al. 1985, Gill et al. 1987, JAAKKOLA et al. 1987). Much of this variation can be attributed to the differences in the quality of the silage offered. According to Dawson et al. (1988), the greatest responses to fish meal have generally been obtained with medium- and poor-quality silages. With highquality silage, reasonable (above $0.9 \mathrm{~kg} / \mathrm{d}$ ) LW gains can be achieved even when silage 
is given alone (Lampila et al. 1988). The responses to protein supplements also seem to be related to the level of concentrate supplement and to the live weight of the animal greater effects being observed with small amounts of concentrates and small animals (PIKE et al. 1988). The use of RSM as protein supplement in the present study should also be noted; in general, the best responses have been obtained with fish meal. Better response to RSM than in the present study was obtained by HUHTANEN et al. (1985), but the animals in that study were smaller $(320 \mathrm{~kg}$ at the end of the experiment).

The silage used in the present study was of high quality, in terms of both fermentation characteristics (low concentrations of fermentation acids and ammonia N) and high digestibility ( $D$ value 0.641 ). This, together with the relatively high proportion of concentrate in the diet $(380-440 \mathrm{~g} / \mathrm{kg} \mathrm{DM})$, resulted in a high intake of digestible OM. The absence of response to RSM may therefore at least partly be attributable to high intakes of DOM, and to rumen microbial protein meeting more of the amino acid requirements with consequent smaller requirements of UDP. The low concentration of ammonia $\mathrm{N}$ in the silage may also have contributed to better utilization of silage $\mathrm{N}$ compared with silages of poorer quality. High performance in cattle given high quality of grass silage ad libitum with $2-3 \mathrm{~kg}$ of barley (LAmpILA et al. 1988, present study) would indicate that protein supply is not limiting the growth rate or the partitioning of energy to lean meat deposition in carcass.

Protein requirement per unit of energy decreases with increasing LW of the animal (ARC 1980), so that greater responses to protein supplements can be expected at an early stage of the growing period. This was observed with RSM in the present study. However, the LW gain advantage was completely lost due to the high degree of compensatory growth of animals not given additional protein in the later part of the experiment. STEEN (1988) found similar compensatory growth in experiment where fishmeal was included in a silage based diet. ØRSKOv et al. (1976) and AbDalla et al. (1988) found that the ruminants have an ability to compensate reduced $\mathrm{LW}$ gains through protein undernutrition when the supply of protein is later increased to meet the requirements. Hence, it may not be economical to try to achieve maximal LW gains with protein supplements at $100-250 \mathrm{~kg}$ of $\mathrm{LW}$. As was concluded by STEEN (1989), additional protein should be offered to cattle given silage based diet to enable the concentrate input to be reduced rather than to increase the performance above the optimum.

\section{The effect of barley fibre}

Although barley fibre tended to depress LW gain, the marginal increase in LW gain per unit of an increase in energy intake with barley supplement was small ( $86 \mathrm{~g} / \mathrm{FFU}$ and $8.2 \mathrm{~g}$ / MJ ME). This can partly be attributed to high energy intake and performance on all diets, so that the genetic growth capacity of the animals was more limiting than energy intake per se. In dairy cows given grass silage ad libitum, milk yields have been equal to (HuнtaNEN et al. 1988) or greater (ALA-SEPPÄLÄ et

Table 8. Efficiency of utilization of metabolizable energy (ME) of growing cattle given grass silage ad libitum with different energy supplements.

\begin{tabular}{lccc}
\hline & \multicolumn{3}{c}{ Supplement } \\
\cline { 2 - 3 } & B & BF & F \\
\hline $\begin{array}{l}\text { Metabolizability } \\
\text { of diet }(q)\end{array}$ & 0.625 & 0.597 & 0.565 \\
$\begin{array}{l}\text { ME intake }(\mathrm{MJ} / \mathrm{d}) \\
\begin{array}{l}\text { ME requirement } \\
\text { (MJ/d) }\end{array}\end{array}$ & 80.7 & 77.4 & 72.9 \\
$\begin{array}{l}\text { Difference }(\mathrm{MJ} / \mathrm{d}) \\
\begin{array}{l}\text { Predicted effi- } \\
\text { ciency }\left(k_{f}\right)^{\prime}\end{array}\end{array}$ & 74.1 & 77.2 & 75.6 \\
$\begin{array}{l}\text { Estimated effi- } \\
\text { ciency }\left(k_{f}\right)^{2}\end{array}$ & 0.493 & 0.472 & 0.447 \\
$\begin{array}{l}\text { Proportion of ME } \\
\text { from digestible }\end{array}$ & 0.423 & 0.477 & 0.499 \\
cell walls & & & \\
\hline
\end{tabular}

$k_{f}=0.78 q+0.006$ (ARC 1980).

${ }^{2}$ Estimated energy retention/(ME intake-ME requirement for maintenance) (ARC 1980). 
al. 1988) with barley fibre than with barley supplement. The efficiency of the utilization of corn gluten feed, a by-product of the corn wet milling process, was $87-100 \%$ that of corn depending on the type of diet and the level and type of corn gluten feed (GREEN et al. 1987).

Estimated utilization of ME above maintenance $\left(k_{f}\right)$ was lower on B diets than predicted from ARC equations (1980), and the opposite was true on $\mathrm{F}$ diets (Table 8). According to our results, q (ME/GE) does not provide an adequate basis for the prediction of $\mathrm{k}_{\mathrm{f}}$. Tномаs et al. (1988) suggested that the nature of ME may influence the efficiency, and in their study there was an inverse relationship between the proportion of ME derived from digestible cell walls and observed efficiency. The present results are in disagreement with those of Tномаs et al. (1988), since here the estimated $k_{f}$ increased with the proportion of digestible cell walls. A similar trend was also observed by JAAKKOLA and HuhtANEN (1989), who compared barley and unmolassed sugar beet pulp in the grass silage based diets of growing cattle.

Three points may be relevant to these conflicting results. First, the nature of the digestible cell walls was different. In the study of Tномаs et al. (1988) the proportion of digestible cell walls in ME intake was increased by decreasing the proportion of barley in the diet, whereas in the present study and that of JAAKKOLA and HuHTANEN (1989) the increase was achieved by increasing the NDF content of the concentrate. Second, the silage of the present study was much less extensively fermented than that of Tномаs et al. (1988), with a much lower ammonia $\mathrm{N}$ content (47 $v$. $120-124 \mathrm{~g} / \mathrm{kg}$ total $\mathrm{N})$. Third, Thomas et al. (1988) used steers and we used bulls.

There is also considerable room for error in this kind of calculation. ME intakes may be biased. Nylon bag incubations (HUHTANEN 1989, unpublished) and digestibility studies (HuhtANEn et al. 1988, 1989, unpublished) suggest no reason for a higher the digestibility of silage with barley fibre than with barley at this level of supplementation, or for a higher digestibility of barley fibre in cattle than in sheep. Higher propionate to butyrate ratio in rumen VFA in cattle given barley fibre than in those given barley (HUHTANEN 1989, unpublished) would reduce methane losses to some extent and thereby increase the metabolizability of BF and $\mathrm{F}$ diets. Higher molar proportion of propionate of rumen VFA with barley fibre diets than with barley diets (Huhtanen, unpublished) may have provided more precursors $\left(\mathrm{NADPH}_{2}\right.$ and glycerol phosphate) for the conversion of acetate to fatty acids, which could explain the higher efficiency of utilization of ME with barley fibre diets. Also, the energy content of the LW gain may be different for the three diets. Higher $k_{f}$ on barley fibre diets suggests that the protein to fat ratio was more favourable than on barley diets. Carcass classification did not indicate any major differences in the fatness of the carcasses, although on the basis of the ARC (1980) system there would be $140 \mathrm{~g} /$ day more fat deposition on diet $\mathrm{B}$ than on diet $\mathrm{F}$.

It is concluded that barley protein has no value as a protein source for growing cattle. Moreover, in conditions like those of the present study, with high quality silage and approximately $400 \mathrm{~g}$ of concentrates per $\mathrm{kg}$ DM intake, no response to supplementation with RSM can be expected. Although LW gains were slightly less with barley fibre than with barley, the performance on barley fibre diets was much better than could be expected from its proportionally 0.22 lower energy value determined in digestibility trials in sheep. The high estimated efficiency of the utilization of diets containing barley fibre compared with diets containing barley indicates either efficient use of ME or changes in the fat to protein ratio of gain.

Acknowledgements. The authors thank Mrs. Sirkka Käyhkö, Miss Pirjo Korhonen and Mr. Juhani Vuorenmaa for technical assistance and the laboratory staff for chemical analyses. The financial support of Alko Ltd. is greatfully acknowledged. 


\section{References}

Abdal..a, H.O., Fox, D.G. \& Thonney, M.L. 1988. Compensatory gain by Holstein calves after underfeeding protein. Anim. Sci. 66: 2687-2695.

(ARC) Agricultural Research Council 1984. The Nutrient Requirements of Ruminants. Supplement 1. Commonwealth Agricultural Bureaux. 44 pp. London.

- 1980. The Nutrient Requirements of Ruminants. Commonwealth Agricultural Bureaux. 351 pp. London.

Ala-Seppãlā, H., Huhtanen, P. \& Näsi, M. 1988. Silage intake and milk production in cows given barley or barley fibre with or without dried distillers solubles. J. Agric. Sci. Finl. 60: 723-733.

Aronen, I. 1988. Barley protein feed as protein supplement for growing cattle. Symposium on Developments in the USE OF Non-conventional Feeds in Ruminant Nutrition. Geneva. $17 \mathrm{pp}$.

Dawson, J.M., Bruce, C.I., Buttery, P.J., Gill, M. \& Beever, D.E. 1988. Protein metabolism in the rumen of silage-fed steers: effect of fishmeal supplementation. Br. J. Nutr. 60: 339-353.

England, P. \& Gill, M. 1985. The effect of fish meal and sucrose supplementation on the voluntary intake of grass silage and live weight gain of young cattle. Anim. Prod. 40: 259-265.

Gil.., M., Beever, D.E., Buttery, P.J., England, P., GıвB, M.J. \& BAKER, R.D. 1987. The effect of oestradiol-17 implantationon the response in voluntary intake, live weight gain and body composition to fish meal supplementation of silage offered to growing calves. J. agric. Sci., (Camb.) 108: 9-16.

Green, D.A., Stock, R.A., Goedeken, F.K. \& Klopfen. STEIN, T.J. 1987. Energy value of corn wet milling byproduct feeds for finishing ruminants. J. Anim. Sci. 65: 1655-1666.

Huhtanen, P. 1987. The effect of dietary inclusion of barley, unmolassed sugar beet pulp and molasses on milk production, digestibility and digesta passage in dairy cows given silage based diet. J. Agric. Sci. Finl. 59: $101-120$.

-, Ala-Seppál.̄, H. \& Nisi, M. 1988. Response of silage intake and milk production to replacement of barley by barley fibre derived from integrated starchethanol process. J. Agric. Sci. Finl. 60: 711-721.

- \& Poutiainen, E. 1985. Effect of full-fat rapeseed on digestibility and rumen fermentation in cattle. $\mathbf{J}$. Agric. Sci. Finl. 57: 67-73.

-, Poutiainen, E. \& Miknoi.A, T. 1985. The effect of supplementation of grass silage with rapeseed meal or Gasol-treated barley on the performance of growing cattle. J. Agric. Sci. Finl. 57: 75-84.

JaAkola, S. \& Huhtanen, P. 1989. The response to cellulase treatment of silage and replacement of barley with unmolassed sugar beet pulp in the diets of growing cattle. Submitted.
-, Huhtanen, P. \& Vanhatalo, A. 1989. Fermentation quality of grass silage treated with enzymes or formic acid and nutritive value in growing cattle fed with or without fish meal. Submitted.

Kassem, M.M., Thomas, P.C., Chamberlain, D.G. \& ROBERTSON, S. 1987. Silage intake and milk production in cows given barley supplements of reduced ruminal degradability. Grass \& Forage Sci. 42: 175-183.

Kırby, P.S., Chalmers, A.J. \& Hannam, D.A.R. 1983. Fish meal supplementation of grass silage diets for fattening British Friesian steers. Anim. Prod. 36: 538. (Abstr.).

-, Outhwaite, J.R. \& Jones, T.O. 1984. A comparison of two types of fish meal as protein supplements for finishing beef cattle given grass silage ad libitum. Anim. prod. 38: 551. (Abstr.).

Lampila, M., Jaakkola, S., Toivonen, V. \& Setálä, J. 1988. Forage conservation and supplementation in cattle rations. Proc. VI World Conf. on Anim. Prod. pp. 51-71. Helsinki.

MAFF (Ministry of Agriculture, Food and Fisheries) 1975. Energy allowances and feeding systems for ruminants. Technical Bulletin 33. 79 p. London.

NAsı, M. Evaluation of barley ethanol feed fractions from integrated barley ethanol-starch process in diets of ruminants. J. Agric. Sci. Finl. 60: 701-709.

Ørskov, E.R., McDonald, 1., Grubb, D.A. \& Pennie, K. 1976. Nutrition of early weaned lamb. IV. Effects on growth rate, food utilization and body composition of changing from a low to a high protein diet. J. agric. Sci., (Camb.) 86: 41423.

Pike, I.H., Smith, G. \& Miller, 1.L. 1988. An evaluation of fish meal as a supplement for beef cattle. Proc. VI World Conf. on Anim. Prod. p. 427. Helsinki.

Storm, E. \& Ørskov, E.R. 1984. The nutritive value of rumen micro-organisms in ruminants. 4 . The limiting amino acids in growing sheep determined by a new approach. Br. J. Nutr. 52: 613-620.

SteEn, R.W.J. 1989. A comparison of soya-bean, sunflower and fish meals for yearling cattle offered grass silage based diets. Anim. Prod. 48: 81-89.

- 1988. The effect of additive treatment of grass silage and food additive avoparcin on the response of calves to supplementation of silage-based diets with fish meal. Anim. Prod. 47: 245-252.

- 1985. Protein supplementation of silage-based diets for calves. Anim. Prod. 41: 293-300.

— \& Moore, C.A. 1988. A comparison of silage-based and dried forage-based diets for finishing beef cattle. Anim. Prod. 47: 29-37.

Thomas, C., Gibb, B.G., Beever, D.E. \& Thurnham, B.R. 1988. The effect of date of cut and barley substitution on gain and on the efficiency of the utiliza- 
tion of grass silage by growing cattle. $\mathrm{Br}$. J. Nutr. 60: 297-306.

Thornton, J.H., Owens, F.N., Williams, D.E. \& Ar. NOLD, M. 1977. Fermentation and digestion of formaldehyde treated ensiled high moisture corn grain. Okla. Agr. Exp. Sta. MP-101: 62-67.

\section{SELOSTUS}

\section{Integroidun ohratärkkelys-etanoliprosessin sivutuotteet lihanautojen ruokinnassa}

\author{
Pekka Huhtanen, Matti Näsi ja \\ Hannele Khalili \\ Helsingin yliopisto, kotieläintieteen laitos, \\ 00710 Helsinki
}

Tärkkelys-etanoliprosessin sivutuotteiden vaikutuksia kasvavien nautojen ruokinnassa tutkittiin kahdessa eri kokeessa. Kokeessa 1 koejärjestelynă oli $4 \times 4$ Latinalainen neliō, jossa selvitettiin ohravalkuaisrehun ( $37.5 \%$ raakavalkuaista kuiva-aineessa) vaikutusta dieetin sulavuuteen ja typen pidăttymiseen neljällă sonnilla (elopaino kokeen alussa keskimäärin $147 \mathrm{~kg}$ ). Kontrolliruokinnalla $(C)$ eläimet saivat ohraa ja heinaaả $(1: 1)$. Koeruokinnoilla osa ohrasta korvattiin soijarouheella (S), soijarouheen ja ohravalkuaisrehun seoksella (SB) tai ohravalkuaisrehulla (B). Dieetin raakavalkuaispitoisuus oli Cruokinnalla $12.5 \%$ ja koeruokinnoilla $15.0 \%$.

Ruokinnoilla ei ollut vaikutusta orgaanisen aineen sulavuuteen, mutta dieetin raakavalkuaisen näennaaistă sulavuutta lisãvalkuaisen antaminen paransi merkitsevästi $(\mathrm{P}<0.01)$. Soijarouheen korvaaminen ohravalkuaisrehulla văhensi typen pidăttymistă lineaarisesti $32.0 \mathrm{~g}$ :sta 28.9 g:aan/pv $(\mathrm{P}<0.05)$. Dieetin valkuaispitoisuuden lisääminen yksistäăn ohravalkuaisrehulla ei lisännyt typen pidăttymistă ohra-heinäruokintaan verrattuna.

Kokeessa 2 tutkittiin ohrarehun (56.6 \% NDF, $13.7 \%$ raakavalkuaista kuiva-aineessa) tuotantovaikutusta kasvavilla sonneilla, jotka saivat säilörehua vapaasti. Koe teh-
WATErhoust, A., LAIRD, R. \& Hol.I.IDAY, R.J. 1984. A response to protein supplementation of grass silage for growing cattle. Anim. Prod. 36: 503. (Abstr.).

Ms received May 25, 1989 tiin $3 \times 2$ faktoriaalisena kokeena, jossa väkirehuina olivat ohra (B), ohran ja ohrarehun seos (1:1) (BF) ja ohrarehu (F), jotka annettiin joko ilman lisãvalkuaista tai yhdessä rypsirouheen $(0.5 \mathrm{~kg} / \mathrm{pv})$ kanssa. Văkirehua annettiin $45 \mathrm{~g} \mathrm{ka} / \mathrm{kg} \mathrm{W}^{0.75}$ rypsirouhe mukaan luettuna. Koe-elăimină oli 24 sonnia ja koe kesti 224 pv.

Kokeessa käytetty sảilörehu oli sekă kàymislaatunsa ettă sulavuutensa puolesta hyvälaatuista, ja dieetin kuivaaineen syönti oli runsasta $\left(96 \mathrm{~g} / \mathrm{kg} \mathrm{W}^{0.75}\right)$. Rypsirouheella ei ollut vaikutusta săilörehun syöntiin eikă lisäkasvuun. Ensimmäisen 16 viikon aikana rypsirouhe lisăsi paaivăkasvua $93 \mathrm{~g}$, mutta tămă ero kompensoitui tảydellisesti kokeen loppupuolella. Vảkirehuilla ei ollut merkitsevảả vaikutusta săilöı ehun tai kuiva-aineen syöntiin. Ohran korvaaminen ohrarehulla văhensi hieman lisăkasvua (1278 g:sta 1214 g:aan/pv; P>0.1). Rehun muuntosuhde $(\mathrm{Ry} / \mathrm{LK}-\mathrm{kg})$ parani lineaarisesti $(\mathrm{P}<0.05)$ korvattaessa ohraa ohrarehulla. Laskelmat energian hyväksikäytöstä osoittivat, ettă ohrarehun tuotantovaikutus oli selvästi parempi kuin lampailla määritettyjen sulavuuskerrointen perusteella voisi paaătellă. Tuotantokokeen perusteella ohrarehun energia-arvoksi tuli noin $90 \%$ ohran arvosta. 